\title{
A THEMATIC LITERATURE REVIEW ON SUKUK
}

\author{
Fareiny Morni \\ Universiti Teknologi MARA \\ Email: fareiny@uitm.edu.my
}

\begin{abstract}
Although there has been extensive research being done in the field of Islamic finance, literature on sukuk are inadequate. This paper intends to present a thematic review of this subject matter. Through a thematic and chronological review, this paper is divided into the following themes; the first two sections are general i.e. we begin with an overview on the structure and nature of a sukuk contract, and the theories that have been adopted in sukuk research. While the remaining sections are separated according to the type of research i.e. a comparison between sukuk and bonds and investors' perception of sukuk, and the impact of sukuk on economic growth. Besides providing a summary of the main points covered in current literature, this paper also highlight trends and issues on sukuk research and provide insight on limitation of current research as well as suggest future research directions.
\end{abstract}

Key Words: Sukuk, Capital Market, Literature Review, Islamic Bond, Islamic finance

\section{A. Introduction}

The Securities Commission Malaysia (2012) define sukuk as "certificates of equal value which evidence undivided ownership or investment in the assets using Shariah principles and concepts endorsed by the Shariah Advisory Council (SAC), but shall not include any agreement for a financing/investment where the financier/ investor and customer/ investee are signatories to the agreement and where the financing/ investment of money is in the ordinary course of business of the financier/investor, and any promissory note issued under the terms of such an agreement." In short, sukuk is a financial document evidencing the transfer of funds between investors and the sukuk issuer - in return for ownership and a share profits on/ from specified assets owned by the issuer.

Research on sukuk have divided the instrument into two (2) categories: exchange-based sukuk and partnership sukuk. Exchange-based sukuk are sukuk that involve a transfer of assets from the sukuk issuer to sukuk investors. While partnership sukuk are sukuk where sukuk investors inject funds into the issuing firm and become partners with the firm. In the first category, sukuk structures such as murabahah, ijarah, bay' bithamanajil, musawamah are used. Whereas in the second category, sukuk structures such as mudharabah and musyarakah are used.

The diverse selection of Islamic contracts that can be used to formulate a sukuk structure differentiates sukuk from conventional financial instruments. Unlike bonds, due to the nature of the underlying contract, each sukuk is designed differently and can be tailored specifically toward the needs and business structure of the issuer. However, very few studies have explored the contractual differences between sukuk structures and those that do focuses on individual contracts and answers the question of whether the instrument is Shariah-compliant (Razak, Saiti, \& Dinç, 2019; Saripudin, Mohamad, Razif, Abdullah, \& Rahman, 2012; Tariq, 2004)or whether it fulfils the requirement as stipulated by the Securities Commission Malaysia (SC) and/ or AAOIFI. 
Hence this paper attempts to shed light on the evolution of literature in sukuk, beginning with the structure and nature of sukuk- focusing on the difference between the two categories of sukuk, exchange-based sukuk and partnership sukuk as well as the difference between sukuk and bonds. Other than that, this paper will also provide a summary of findings in relation to investors' perception of sukuk and the impact of sukuk on economic growth. This paper provides critical information for sukuk research and can be used as a reference point for future studies in Islamic capital market research.

\section{A.1. Methodology}

Due to the limited number of available literatures, this paper utilizes the snowball approach in collecting relevant literature on the subject matter. We begin by searching databases such as Scopus, Web of Science, and Google Scholar using the following keywords such as sukuk, partnership sukuk, exchange-based sukuk, sukuk structure, sukuk vs bonds and impact of sukuk.

Backward snowballing is used where we identify citations in a suitable paper to determine similar works on the subject matter (Wee \& Banister, 2016). Hence only thirty (30) of selected papers which have been published in the past 13 years i.e. from 2007 until 2019are selected and arranged in a chronological order.

\section{B. Literature Review: Structure and Nature of Sukuk}

Depending on the type of firm issuing the sukuk - be it a parent/ holding company or a special-purpose vehicle (SPV) which was created specifically for the sukuk issuance, a sukuk contract would be drafted to specify the role of the sukuk issuer, the underlying contract used, the underlying asset supporting the financial obligation evidenced in the sukuk and the estimated profit rate (for exchange-based sukuk)/ profit sharing ratio (for partnership sukuk). There is a significant difference between how an exchange-based sukuk and partnership sukuk is managed as well as arising issues surrounding these two sukuk structures.

Table 1 Exchange-Based Sukukvs Partnership Sukuk

\begin{tabular}{|c|c|c|}
\hline & Exchange-Based Sukuk & Partnership Sukuk \\
\hline $\begin{array}{l}\text { Role of } \\
\text { Issuer }\end{array}$ & $\begin{array}{l}\text { Depending on the contract, the } \\
\text { issuer either sells or leases an } \\
\text { asset to the sukuk investors and } \\
\text { later may repurchase the asset } \\
\text { from the investors. The purpose } \\
\text { of the sale of asset is for fund- } \\
\text { raising purposes only. }\end{array}$ & $\begin{array}{l}\text { Depending on the nature of } \\
\text { the contract, the issuer can be a } \\
\text { partner or an agent to sukuk } \\
\text { investors i.e. the investors } \\
\text { form a partnership among } \\
\text { themselves and appoint the } \\
\text { issuer as their agent. }\end{array}$ \\
\hline $\begin{array}{l}\text { Underlying } \\
\text { Contracts }\end{array}$ & $\begin{array}{lll}\text { Murabahah, Ijarah, } & \text { Bay' } \\
\text { bithamanajil, Musawamah, Bay' } \\
\text { Salam, Istisna', Tawarruq, Bay' } \\
\text { al-Inah }\end{array}$ & Mudharabah, Musyarakah \\
\hline $\begin{array}{l}\text { Underlying } \\
\text { Asset }\end{array}$ & \multicolumn{2}{|c|}{$\begin{array}{l}\text { The underlying asset must be Shariah-compliant. It can be } \\
\text { tangible and/or intangible and receivables can also be used as } \\
\text { long as the receivables are established, certain and transacted on } \\
\text { cash basis (on spot). }\end{array}$} \\
\hline
\end{tabular}




\begin{tabular}{|l|l|l|}
\hline Issues & $\begin{array}{l}\text { The existence of asset-based } \\
\text { sukuk instead of asset-backed } \\
\text { sukuk. }\end{array}$ & $\begin{array}{l}\text { The proliferation of agency } \\
\text { issues in partnership } \\
\text { contracts. }\end{array}$ \\
$\begin{array}{l}\text { An increasing number of } \\
\text { sukuk defaults especially for } \\
\text { asset-based sukuk. }\end{array}$ & $\begin{array}{l}\text { Guarantee of principal } \\
\text { repayment. } \\
\text { Purchase of shares at } \\
\text { nominal value instead of } \\
\text { market value. }\end{array}$ \\
\cline { 2 - 4 } & $\begin{array}{l}\text { Sukuk returns are benchmarked to interest or conventional } \\
\text { bonds. }\end{array}$ \\
$\begin{array}{l}\text { The use of debt as the underlying asset. } \\
\text { Lack of alternatives for the issuer and investor to manage } \\
\text { exposure to liquidity, market, interest rate, and foreign- } \\
\text { exchange risks. }\end{array}$
\end{tabular}

Sources: Adopted and compiled from Howladar(2009), Muhammad Al-Amine (2008), Securities Commission Malaysia (2012) and Usmani (2008)

Early literature on sukuk structures have highlighted a number of issues in sukuk structures - criticising that the existence of several mechanisms has turned sukuk similar to bonds. Hence, it would be prudent to begin with Usmani (2008) ruling on sukuk. According to Usmani, there exist three (3) mechanism in current sukuk structures that allow sukuk to bear similar resemblance to bonds:

Table 2Usmani's Ruling on Sukuk

\begin{tabular}{|l|l|}
\hline \multicolumn{1}{|c|}{ Mechanism } & \multicolumn{1}{c|}{ Shariah Implication } \\
\hline $\begin{array}{l}\text { Allowing the manager/ } \\
\text { sukuk issuer to keep excess } \\
\text { profits as an incentive for } \\
\text { good investment }\end{array}$ & $\begin{array}{l}\text { Majority jurists find it to be makruh due to } \\
\text { ignorance on the exact value of the fee received } \\
\text { by the sukuk issuer as agent to sukuk partners. } \\
\text { However, a number of jurists allow for tanazul } \\
\text { with the condition that the fee received by the } \\
\text { sukuk issuer is known and it is pre-agreed } \\
\text { between the sukuk issuer and investors that if } \\
\text { profits received from the venture is beyond a } \\
\text { certain percentage, the issuer may exclusively } \\
\text { enjoy the excess profits. }\end{array}$ \\
\hline $\begin{array}{l}\text { Allowing the manager/ } \\
\text { sukuk issuer to lend the value } \\
\text { of shortfall if profits are less } \\
\text { than expected amount. }\end{array}$ & $\begin{array}{l}\text { The Prophet p.b.u.h. prohibited the practice } \\
\text { linking sales to credit in a hadith narrated by } \\
\text { Imam Malik and Abu Dawud and al-Tirmidhi. }\end{array}$ \\
\hline $\begin{array}{l}\text { Binding promise by bus } \\
\text { manager/ sukuk issuer to } \\
\text { purchase assets at face value } \\
\text { at maturity }\end{array}$ & $\begin{array}{l}\text { Commitment by the sukuk issuer to purchase } \\
\text { sukuk assets at face value upon maturity } \\
\text { regardless of the true value of the asset becomes } \\
\text { capital guarantee by the mudharib/ musyarik to } \\
\text { the investors and there is no justification for the } \\
\text { commitment made by the mudharib/musyarik. }\end{array}$ \\
\hline
\end{tabular}

These mechanisms are mainly used in wakalah, mudharabah and musyarakah sukuk. And although Usmani have strongly criticised the application of these 
mechanism in sukuk, it appears that they are still in use in a number of partnership and agency sukuk contracts today.

Muhammad Al-Amine (2008) has also provided several criticisms on existing sukuk structures. Some of the criticisms are in regards to the partnership structure of musyarakah and similar to what has been voiced out by Usmani (2008). However, there are additional criticisms such as:

(1) The use of guarantee in ijarah sukuk;

(2) The application of bay' al-Inah in ijarah sukuk i.e. sale and leaseback contract for the underlying assets;

(3) Sukuk pricing that are benchmarked to LIBOR;

(4) Lack of eligible underlying assets for sukuk; and

(5) Differences of opinion among the different school of thoughts may result in a contract that is frowned upon in one country such as tawarruq is accepted in another country.

For an in-depth examination on the permissibility of the mechanisms adopted in sukuk, Abdul Rahman \& Hasan (2011),Hasan (2011) and Ellias, Haron, \& Mohammed (2013)have provided a lengthy discourse on guarantee of capital, the application of tanazul in musyarakah, and other Shariah issues in sukuk. These authors have not only quoted classical scholars and Imams of the four main schools of thought, but also explained the different ways in which these mechanisms can be implemented and differentiated the application in which it is permissible compared to when it becomes non-permissible.

Later studies that focuses on the capital market and capital market instruments by Godlewski, Turk-Ariss, \& Weill (2011), Lahsasna\& Lin (2012)and including a more recent paper by Razak et al. (2019) continue to highlight similar concerns indicating that the mechanisms are still practiced and implemented in sukuk. These include fixed periodic returns over the sukuk and guarantee of principal for mudharabah and musyarakah sukuk and concerns over the true transfer of ownership of the underlying asset for ijarah sukuk.

\section{Analysis: Theories Adopted in Sukuk Research}

As far as we are aware, no specific theory has been developed for Islamic financial instruments. Existing studies in sukuk adopts investment theories such as capital structure irrelevance theory, trade-off theory, pecking order theory, signalling theory, and agency theory and tries to identify whether sukuk acts in a similar manner to debt or equity instruments.

A study by Haron \& Ibrahim (2012) found that sukuk has a significant impact on the Malaysian bond market development and is employed by firms to manage and adjust towards their target capital structure. Based on the trade-off theory, both sukuk and conventional bond issuers exhibited a target optimizing behaviour; where sukuk issuers demonstrated a faster speed of adjustment compared to conventional bond issuers (Hanifa, Masih, \& Bacha, 2014a).Unlike conventional bond issuers, where profitability was found to have a significant negative effect on conventional bond ratio, profitability was determined to be insignificantly related to sukuk ratio, indicating that sukuk financing is sought by issuers regardless of the availability of internal funds. Hanifa et al. (2014)also found sukuk ratio to be significant and positively affected by the firm's growth opportunity, consistent with pecking order predictions. 
Meanwhile Alam, Hassan, and Haque (2013)have adopted the signalling theory in their study. They found that sukuk announcements result in a negative signal in the market. Based on their study, the authors concluded that weaker companies prefer to issue sukuk, specifically risk-sharing or partnership sukuk in order to minimize their loss in the event of failure while companies that expect to earn high returns prefer to issue bonds to maximize their returns in the event of success. However, a later study by Mahomed (2016)found both exchange-based and partnership sukuk emitted a positive signal before the global economic crisis. However, after the crisis, market reaction only remained positive for exchangebased sukuk. Although partnership sukuk emitted a negative signal after the crisis, the results were insignificant.

\section{Discussions: Type of Sukuk Research}

Sukuk research are mainly divided into three categories: (1) A comparison between sukuk and bonds; (2) Investors perception of sukuk; and (3) The impact of sukuk on economic growth.

\section{D.1 Comparison between Sukuk and Bonds and Investors' Perception of Sukuk}

Is sukuk a similar instrument to bonds? Godlewski, Turk-Ariss, \& Weill (2011) in their paper posed a similar question. They quote Miller, Challoner and Atta (2007) who state that sukuk are structured to ensure an equivalent return to conventional bond, but that return is derived from an underlying asset rather than the obligation to pay interest. They also quote Wilson (2008) who opined that financiers design sukuk to be similar to conventional securities so unfamiliar investors are able to assess the risk of sukuk easily.

According to Usmani (2008), sukuk is different compared to both equity and debt instruments due to the following factors:

(1) Unlike bond or equity, a sukuk certificate represent ownership in a specific underlying asset;

(2) Depending on the underlying sukuk structure, sukuk holders may receive regular payments like bondholders or irregular payments like equity holders; and

(3) Like equity holders, sukuk holders are not guaranteed principal repayment at maturity.

This is supported by a number of authors who affirm sukuk as a different instrument compared to conventional bonds (Alam et al., 2013; Cakir \& Raei, 2007; Godlewski, Turk-Ariss, \& Weill, 2013; Hanifa, Masih, \& Bacha, 2014b; Safari, 2013). However, a deeper investigation reveals contradictory findings while a group of authors state sukuk as different, another group claim sukuk and bonds are the same. Among them is Howladar (2009)who states that current sukuk structures are similar to conventional fixed income instruments from a risk/ return perspective:

(1) Underlying assets have little or no bearing on the risk or performance of the sukuk;

(2) Majority of sukuk contracts do not transfer the ownership of the underlying assets to investors; and

(3) Sukuk returns and cash flows are not linked to the underlying assets. 
To gain a better understanding on the matter, a compilation of selected literature comparing sukuk and bonds have been tabulated in the following table:

Table 3 Literature on Sukukvs Bonds and Investors' Perception of Sukuk

\begin{tabular}{|c|c|c|c|c|}
\hline Year & Title/ Author & Sample & Methodology & Findings \\
\hline 2007 & $\begin{array}{l}\text { Sukuk and their } \\
\text { Contemporary } \\
\text { Applications / } \\
\text { Usmani }\end{array}$ & - & $\begin{array}{l}\text { Discussion } \\
\text { Paper }\end{array}$ & $\begin{array}{l}\text { Highlight criticisms } \\
\text { in the current sukuk } \\
\text { structure such as (1) } \\
\text { The use of debt as } \\
\text { the underlying } \\
\text { asset in sukuk } \\
\text { structures; (2) Fixed } \\
\text { return to sukuk } \\
\text { holders; and (3) } \\
\text { Guarantee of } \\
\text { principal. }\end{array}$ \\
\hline 2009 & $\begin{array}{l}\text { The Future of } \\
\text { Sukuk: } \\
\text { Substance over } \\
\text { Form?/ } \\
\text { Howladar }\end{array}$ & $\begin{array}{c}\text { Selected sukuk } \\
\text { contracts - } \\
\text { Tamweel PJSC } \\
\text { and East } \\
\text { Cameron } \\
\text { Partners L.P. }\end{array}$ & $\begin{array}{l}\text { Commentary/ } \\
\text { Case Study }\end{array}$ & $\begin{array}{l}\text { Current sukuk } \\
\text { structures are } \\
\text { similar to } \\
\text { conventional fixed } \\
\text { income instruments } \\
\text { from a risk/ return } \\
\text { perspective: (1) } \\
\text { Underlying assets } \\
\text { have little or no } \\
\text { bearing on the risk } \\
\text { or performance of } \\
\text { the sukuk; (2) } \\
\text { Majority of sukuk } \\
\text { contracts do not } \\
\text { transfer the } \\
\text { ownership of the } \\
\text { underlying assets to } \\
\text { investors; (3) Sukuk } \\
\text { returns and cash } \\
\text { flows are not linked } \\
\text { to the underlying } \\
\text { assets. }\end{array}$ \\
\hline 2011 & $\begin{array}{l}\text { Do Markets } \\
\text { Perceive Sukuk } \\
\text { and } \\
\text { Conventional } \\
\text { Bonds as } \\
\text { Different } \\
\text { Financing } \\
\text { Instruments?/ } \\
\text { Godlewski, } \\
\text { Turk-Ariss, }\end{array}$ & $\begin{array}{c}\text { Sample period } \\
\text { between } 2002 \\
\text { to } 2009 \\
\text { encompassing } \\
93 \text { events for } \\
\text { bonds and } 77 \\
\text { events for } \\
\text { sukuk from } \\
\text { Malaysia. }\end{array}$ & Event study & $\begin{array}{l}\text { Stock markets are } \\
\text { able to distinguish } \\
\text { between sukuk and } \\
\text { bonds and } \\
\text { recognises the two } \\
\text { instruments as } \\
\text { different. Hence, } \\
\text { investor reaction to } \\
\text { sukuk and bond } \\
\text { announcements are }\end{array}$ \\
\hline
\end{tabular}




\begin{tabular}{|c|c|c|c|c|}
\hline & and Weill & & & different. \\
\hline 2013 & $\begin{array}{l}\text { Compare and } \\
\text { Contrast Sukuk } \\
\text { (Islamic Bonds) } \\
\text { with } \\
\text { Conventional } \\
\text { Bonds, Are } \\
\text { They } \\
\text { Compatible?/ } \\
\text { Afshar }\end{array}$ & - & $\begin{array}{l}\text { Qualitative } \\
\text { Review/ } \\
\text { Discussion } \\
\text { Paper }\end{array}$ & $\begin{array}{l}\text { Bonds and sukuk } \\
\text { are different } \\
\text { instruments that } \\
\text { solve the same } \\
\text { financial problem } \\
\text { i.e. raising capital } \\
\text { for entities. Both } \\
\text { instruments are } \\
\text { structured } \\
\text { differently and } \\
\text { sukuk should } \\
\text { provide greater } \\
\text { return and financial } \\
\text { security compared } \\
\text { to bonds. }\end{array}$ \\
\hline 2014 & $\begin{array}{l}\text { Daily Traders' } \\
\text { and } \\
\text { Institutional } \\
\text { Investors' } \\
\text { Wealth Effect } \\
\text { upon Sukuk } \\
\text { and } \\
\text { Conventional } \\
\text { Bond } \\
\text { Announcement } \\
\text { s: A Case } \\
\text { Study of } \\
\text { Malaysian } \\
\text { Firms Using } \\
\text { Event-Study } \\
\text { Methodology } \\
\text { and Wavelet } \\
\text { Analysis/ } \\
\text { Hanifa, Masih } \\
\text { and Bacha }\end{array}$ & $\begin{array}{l}\text { Sample taken } \\
\text { from the } \\
\text { Malaysian } \\
\text { stock market } \\
\text { with } 158 \\
\text { conventional } \\
\text { bonds and } 129 \\
\text { sukuk issuers } \\
\text { between } 2000 \\
\text { and } 2003\end{array}$ & $\begin{array}{c}\text { Event Study } \\
\text { and Wavelet } \\
\text { Analysis }\end{array}$ & $\begin{array}{l}\text { Market investors } \\
\text { perceive sukuk and } \\
\text { bonds as different } \\
\text { financial } \\
\text { instruments - firm } \\
\text { value and } \\
\text { shareholder wealth } \\
\text { are affected } \\
\text { differently upon the } \\
\text { issuance } \\
\text { announcement of } \\
\text { sukuk and bonds. }\end{array}$ \\
\hline 2015 & $\begin{array}{l}\text { The (Little) } \\
\text { Difference that } \\
\text { Makes All the } \\
\text { Difference } \\
\text { between } \\
\text { Islamic and } \\
\text { Conventional } \\
\text { Bonds / Azmat, } \\
\text { Skully, and } \\
\text { Brown }\end{array}$ & $\begin{array}{l}\text { Sample of } 458 \\
\text { Islamic bonds } \\
\text { from } 83 \\
\text { issuers } \\
\text { covering the } \\
\text { period } \\
\text { between } 2002 \\
\text { to } 2010 \text { from } \\
\text { Malaysia }\end{array}$ & $\begin{array}{c}\text { Ordered Probit } \\
\text { Analysis }\end{array}$ & $\begin{array}{l}\text { There are very few } \\
\text { differences between } \\
\text { conventional and } \\
\text { Islamic instruments } \\
\text { other than in } \\
\text { Islamic structural } \\
\text { differences - in } \\
\text { terms of structure, } \\
\text { some Islamic } \\
\text { instruments are } \\
\text { cosmetically treated } \\
\text { to give an illusion }\end{array}$ \\
\hline
\end{tabular}




\begin{tabular}{|c|c|c|c|c|}
\hline & & & & of difference. \\
\hline 2016 & $\begin{array}{l}\text { Does } \\
\text { Innovation in } \\
\text { Sukuk structure } \\
\text { create Value? } \\
\text { A study of post } \\
\text { crisis Sukuk } \\
\text { wealth effects } \\
\text { in Malaysia/ } \\
\text { Mahomed, } \\
\text { Mohamad, and } \\
\text { Ariff }\end{array}$ & $\begin{array}{l}\text { The crisis } \\
\text { period is } \\
\text { identified } \\
\text { empirically, } \\
\text { using Bai- } \\
\text { Perron (2003) } \\
\text { multiple } \\
\text { breakpoint } \\
\text { analysis. }\end{array}$ & $\begin{array}{l}\text { Event study } \\
\text { methodology } \\
\text { (Market Model) } \\
\text { is used to } \\
\text { determine } \\
\text { market reaction } \\
\text { and the wealth } \\
\text { effect based on } \\
\text { 24 sukuk events. } \\
\text { Both } \\
\text { parametric } \\
\text { (BMP) \& non- } \\
\text { parametric } \\
\text { (Rank) tests are } \\
\text { used for max } \\
\text { robustness. } \\
\text { Scholes- } \\
\text { Williams (1977) } \\
\text { approach was } \\
\text { applied to } \\
\text { adjust for thin } \\
\text { trading \& the } \\
\text { Kolari- } \\
\text { Pynnonen } \\
\text { (2010) test to } \\
\text { remove cross- } \\
\text { correlation } \\
\text { effects. }\end{array}$ & $\begin{array}{l}\text { The market } \\
\text { distinguished } \\
\text { between debt and } \\
\text { equity based sukuk } \\
\text { pre-crisis, } \\
\text { supporting the } \\
\text { conjecture that } \\
\text { financial innovation } \\
\text { creates value for } \\
\text { shareholders. } \\
\text { However, no net } \\
\text { reaction is observed } \\
\text { post-crisis } \\
\text { irrespective of } \\
\text { structure, } \\
\text { indicating the } \\
\text { market's } \\
\text { indifference to } \\
\text { sukuk against } \\
\text { bonds, implying } \\
\text { that sukuk in } \\
\text { Malaysia is no } \\
\text { longer perceived as } \\
\text { a financial } \\
\text { innovation. }\end{array}$ \\
\hline 2017 & $\begin{array}{l}\text { Do Regional } \\
\text { and Global } \\
\text { Uncertainty } \\
\text { Factors Affect } \\
\text { Differently the } \\
\text { Conventional } \\
\text { Bonds and } \\
\text { Sukuk? New } \\
\text { Evidence/ } \\
\text { Naifar, Mroua, } \\
\text { and Bahloul }\end{array}$ & $\begin{array}{c}\text { Sukuk - Dow } \\
\text { Jones Sukuk } \\
\text { Index and } \\
\text { Malaysian } \\
\text { Sukuk Index. } \\
\text { Bonds - Dow } \\
\text { Jones Asia } \\
\text { Bond Index } \\
\text { and Malaysia } \\
\text { Corporate } \\
\text { Bond Index. } \\
\text { Volatility - } \\
\text { VIX Volatility } \\
\text { Index. Global } \\
\text { Economic } \\
\text { Uncertainty - } \\
\text { U.S. Economic } \\
\text { Policy } \\
\text { Uncertainty }\end{array}$ & $\begin{array}{c}\text { Quantile } \\
\text { Regression }\end{array}$ & $\begin{array}{l}\text { Sukuk are different } \\
\text { than conventional } \\
\text { bonds in terms of } \\
\text { co-movement with } \\
\text { global and regional } \\
\text { uncertainty factors } \\
\text { and these two } \\
\text { instruments are } \\
\text { complementary and } \\
\text { not substitutes. }\end{array}$ \\
\hline
\end{tabular}




\begin{tabular}{|l|c|c|l|}
\hline & (EPU) Index. & & \\
& Data from Jan. & & \\
& 2010 until & & \\
& Dec. 2014. & & \\
\hline
\end{tabular}

Based on the information gathered in the above table, we can surmise that existing studies that compares sukuk to bonds are divided into two (2) main camps:

(1) Those who study the underlying structure of sukuk (Afshar, 2013; Azmat et al., 2015; Usmani, 2008) find sukuk to be a similar instrument to bonds due to how the instrument is designed. Although dissimilarities may exist between the two instruments, those differences are small and may even be due to cosmetic enhancements to the underlying structure so as to distinguish sukuk from bonds; and

(2) Those who study market reaction and investors' wealth (Godlewski et al., 2011; Hanifa et al., 2014a; Howladar, 2009; Mahomed et al., 2016; Naifar et al., 2017) claim sukuk and bonds as different instruments. According to them, the market perceives both instruments as different, hence investors react differently to issuance notice of either instrument. Both instruments were also found to be affected differently by regional and global uncertainties which further reinforces the view that sukuk and bonds have dissimilar characteristics.

\section{D.2 The Impact of Sukuk on Economic Growth}

On a macroeconomic perspective, an increasing number of literatures have also investigated the impact of sukuk on economic growth.

Table 4 Literature on Sukuk and Economic Growth

\begin{tabular}{|c|c|c|c|c|}
\hline Year & Title/ Author & Sample & Methodology & Findings \\
\hline 2011 & $\begin{array}{l}\text { Sustainability of } \\
\text { sukuk and } \\
\text { conventional } \\
\text { bond during } \\
\text { financial crisis: } \\
\text { Malaysia's } \\
\text { capital market/ } \\
\text { Ahmad \& Radzi }\end{array}$ & $\begin{array}{l}20 \text { sukuk and } \\
\text { bond issuance } \\
\text { in Malaysia } \\
\text { from the } \\
\text { period } 1990 \text { to } \\
2009 .\end{array}$ & $\begin{array}{c}\text { Regression } \\
\text { analysis. }\end{array}$ & $\begin{array}{l}\text { Sukuk has a } \\
\text { positive } \\
\text { relationship with } \\
\text { GDP, foreign } \\
\text { exchange and } \\
\text { international } \\
\text { liquidity. The } \\
\text { adverse impact of } \\
\text { financial crisis on } \\
\text { sukuk is lesser } \\
\text { compared to } \\
\text { bonds. }\end{array}$ \\
\hline 2017 & $\begin{array}{l}\text { How do } \\
\text { sovereign } \\
\text { sukukimpact on } \\
\text { the economic } \\
\text { growth of } \\
\text { developing } \\
\text { countries? An }\end{array}$ & $\begin{array}{c}\text { Sovereign } \\
\text { sukuk } \\
\text { issuances in } \\
\text { Malaysia and } \\
\text { Saudi Arabia } \\
\text { between } 2002 \\
\text { to } 2011 .\end{array}$ & $\begin{array}{l}\text { Paired sample } \\
\text { t-test on panel } \\
\text { data } \\
\text { comprising of } \\
\text { economic, } \\
\text { state financial } \\
\text { and social }\end{array}$ & $\begin{array}{l}\text { Sovereign sukuk } \\
\text { issuances have a } \\
\text { positive impact on } \\
\text { the economic } \\
\text { development of } \\
\text { Malaysia and } \\
\text { Saudi Arabia. }\end{array}$ \\
\hline
\end{tabular}




\begin{tabular}{|c|c|c|c|c|}
\hline & $\begin{array}{l}\text { analysis of the } \\
\text { infrastructure } \\
\text { sector/ Malikov }\end{array}$ & & $\begin{array}{l}\text { development } \\
\text { indicators. }\end{array}$ & \\
\hline 2017 & $\begin{array}{l}\text { Impact of sukuk } \\
\text { market } \\
\text { development on } \\
\text { Indonesian } \\
\text { economic } \\
\text { growth/ } \\
\text { Mitsaliyandito, } \\
\text { Arundina, \& } \\
\text { Kasri }\end{array}$ & $\begin{array}{c}\text { Quarterly } \\
\text { data of } \\
\text { outstanding } \\
\text { sukuk from } \\
2009 \text { - } 2016 \text {. }\end{array}$ & $\begin{array}{l}\text { VAR model } \\
\text { and Granger } \\
\text { causality test. }\end{array}$ & $\begin{array}{l}\text { Domestic } \\
\text { sovereign sukuk } \\
\text { market has a } \\
\text { positive influence } \\
\text { on Indonesian } \\
\text { GDP bigger than } \\
\text { the corporate } \\
\text { market. }\end{array}$ \\
\hline 2017 & $\begin{array}{l}\text { Does sukuk } \\
\text { market } \\
\text { development } \\
\text { spur economic } \\
\text { growth?/ Smaoui } \\
\text { \& Nechi }\end{array}$ & $\begin{array}{l}\text { All sukuk } \\
\text { issuing } \\
\text { countries } \\
\text { from the } \\
\text { period } 1995 \text { - } \\
2015 .\end{array}$ & System GMM & $\begin{array}{l}\text { Sukuk market } \\
\text { development is } \\
\text { conducive to } \\
\text { economic growth } \\
\text { i.e. the } \\
\text { development of } \\
\text { sukuk market may } \\
\text { have promoted } \\
\text { financial inclusion } \\
\text { by eliminating the } \\
\text { negative effects of } \\
\text { religious self- } \\
\text { exclusion, which } \\
\text { stimulates } \\
\text { investment and } \\
\text { economic growth. }\end{array}$ \\
\hline
\end{tabular}

Although the number of literatures are limited, sukuk has been found to have a positive impact on economic growth. It is foreseen that more studies should be conducted on the impact of sukuk on economic growth especially in Middle East and African countries where there has been an increase in sukuk issuances over the past few years.

\section{E. Conclusion: Limitation of Current Research and Recommendation}

This paper has provided a selection of literature that encompass different themes - investigation into the underlying structure and nature of sukuk, comparison between sukuk and its conventional counterpart i.e. bonds, investors' perception of sukuk i.e. do investors see sukuk as a similar instrument to bonds, adoption of finance theories into sukuk research and the impact of sukuk on economic growth.

In the beginning, sukuk literature was geared extensively towards qualitative research where scholars investigated the various mechanisms used in structuring sukuk and question the origin of those mechanisms. As the number of Shariah compliant instruments increased, studies in sukuk evolved into quantitative research and moved towards measuring the impact and performance of sukuk and comparing sukuk with bonds. There still exist many 
gaps in existing research for sukuk, among them are the impact of default sukuk on the sukuk issuer or the obligor and this can be quantified in many ways such as impact on shareholders' wealth, impact on firm share price as well as impact on the obligor's cash flow and risk. Another aspect that has yet to be explored is the introduction of new hybrid sukuk i.e. sukuk that consist of two or more underlying contracts such as wakalah and istisna', musyarakah and ijarah and many more. There is an increase in the use of hybrid sukuk especially in Malaysia and so far, there has yet to be a study investigating the performance, risk, and impact of hybrid sukuk.

As for limitation for current research on sukuk, it is evident that most sukuk research are mainly focused on sukuk issued in Malaysia, Indonesia and GCC countries. In recent times, we have seen sukuk being issued by financial centres such as Hong Kong and London and to our knowledge there are no research (both qualitative and quantitative) on sukuk issued by these financial centres.

In conclusion, it can be said that as the sukuk market grow and matures, there is still a need for research on current sukuk structures and its impact both on a macro and micro perspective. This paper has presented several important findings on sukuk and it is evident that there is a need for more research to be done on the sukuk instrument.

\section{Bibliography}

Abdul Rahman, Z., \& Hasan, A. (2011). Musharakah dan Mudarabah: Isu Jaminan Perlindungan Modal bagi Pengukuhan Kredit. In Muzakarah Cendekiawan Syariah Nusantara 2011.

Afshar, T. A. (2013). Compare and Contrast Sukuk ( Islamic Bonds ) with Conventional Bonds, Are they Compatible? Journal of Global Business Management, 9(1), 44-52.

Ahmad, W., \& Radzi, R. M. (2011). Sustainability of sukuk and conventional bond during financial crisis: Malaysia's capital market. Global Economy and Finance Journal, 4(2), 33-45.

Alam, N., Hassan, M. K., \& Haque, M. A. (2013). Are Islamic bonds different from conventional bonds? International evidence from capital market tests. Borsa Istanbul Review, 13(3), https:/ / doi.org/http:/ / dx.doi.org/10.1016/j.bir.2013.10.006

Azmat, S., Skully, M., \& Brown, K. (2015). The (little) difference that makes all the difference between Islamic and conventional bonds. Pacific-Basin Finance Journal, 42, 46-59.

Cakir, S., \& Raei, F. (2007). Sukuk vs. Eurobonds: Is there a Difference in ValueAt-Risk? International Monetary Fund Working Paper, 07(237), 1. https:// doi.org/10.5089/9781451868012.001

Ellias, M. R. F., Haron, M. N., \& Mohammed, M. F. (2013). Shariah Issues in Sukuk. In Shariah Forum, KLIFF. Kuala Lumpur. Retrieved from https://www.maybank2u.com.my/iwov-resources/islamicmy/document/my/en/islamic/scoe/knowledge-centre/researchpaper/Shariah_Issues_in_Sukuk.pdf

Godlewski, C. J., Turk-Ariss, R., \& Weill, L. (2011). Do markets perceive sukuk and conventional bonds as different financing instruments?BOFIT- Institute for Economies in Transition, Bank of Finland. 
https:/ / doi.org/10.1080/13651820500534892

Godlewski, C. J., Turk-Ariss, R., \& Weill, L. (2013). Sukuk vs. conventional bonds: A stock market perspective. Journal of Comparative Economics, 41(3), 745-761. https:// doi.org/10.1016/j.jce.2013.02.006

Hanifa, M. H., Masih, A. M. M., \& Bacha, O. I. (2014a). Daily Traders' and Institutional Investors' Wealth Effect upon Sukuk and Conventional Bond Announcements: A Case Study of Malaysian Firms Using Event-Study Methodology and Wavelet Analysis. Capital Markets Review, 22, 59-81.

Hanifa, M. H., Masih, M., \& Bacha, O. I. (2014b). Testing Sukuk And Conventional Bond Offers Based On Corporate Financing Theories Using Partial Adjustment Models: Evidence From Malaysian Listed Firms.

Haron, R., \& Ibrahim, K. (2012). The Impact of Sukuk on Corporate Financing: Malaysia Evidence. Journal of Islamic Finance, 1(1), 1-11.

Hasan, A. (2011). Perlaksanaan Tanazul Di Dalam Kontrak Berdasarkan Musharakah: Perspektif Syarak. In Seminar on Shariah Issues in Musharakah and Mudharabah, Conference by Shariah Advisory Council BNM and Shariah Advisory Council SC. Retrieved from https://www.maybank2u.com.my/iwov-resources/islamicmy/document/my/en/islamic/scoe/knowledge-centre/researchpaper/Tanazul_Dalam_Kontrak_Musharakah.pdf

Howladar, K. (2009). The future of Sukuk: substance over form ? Islamic Finance Analysis, 1-7.

Lahsasna, A., \& Lin, L. S. (2012). Issues in Islamic Capital Markets: Islamic Bond/Sukuk. 3rd INTERNATIONAL CONFERENCE ON BUSINESS AND ECONOMIC RESEARCH, (March), 495-512.

Mahomed, Z. (2016). Wealth Effects of Corporate Sukuk Announcements and Risk Dynamics: A Multi-Country Study. INCEIF.

Mahomed, Z., Mohamad, S., \& Ariff, M. (2016). Does Innovation in Sukuk structure create Value? A study of post-crisis Sukuk wealth effects in Malaysia. In World Islamic Finance Forum (WIFF) 2016. Karachi, Pakistan: Institute of Business Administration.

Malikov, A. (2017). How Do Sovereign Sukuk Impact on the Economic Growth of Developing Countries? An Analysis of the Infrastructure Sector. In Critical Issues and Challenges in Islamic Economics and Finance Development (pp. 1-37). Springer.

Miller, N. D., Challoner, J., \& Atta, A. (2007). UK Welcomes the Sukuk-How the UK Finance Bill Should Stimulate Islamic Finance in London, Much to the Delight of the City's Banks. Int'l Fin. L. Rev., 26, 24.

Mitsaliyandito, R. Q., Arundina, T., \& Kasri, R. A. (2017). Impact of sukuk market development on Indonesian Economic growth. International Journal of Applied Business and Economic Research, 15(24), 537-549.

Muhammad Al-Amine, M. A.-B. (2008). Sukuk market: Innovations and challenges. In Islamic Capital Markets: Products, Regulations and Development (pp. 33-54).

Naifar, N., Mroua, M., \& Bahloul, S. (2017). Do regional and global uncertainty factors affect differently the conventional bonds and sukuk? New evidence. Pacific-Basin Finance Journal, 41, 65-74.

Razak, S. S., Saiti, B., \& Dinç, Y. (2019). The contracts, structures and pricing mechanisms of sukuk: A critical assessment. Borsa Istanbul Review, 19, S21- 
S33.

Safari, M. (2013). Contractual structures and payoff patterns of Sukūk securities. International Journal of Banking and Finance, 10(2), 1-27.

Saripudin, K. N., Mohamad, S., Razif, N. F. M., Abdullah, L. H., \& Rahman, N. N. A. (2012). Case study on sukuk musharakah issued in Malaysia. Middle-East Journal of Scientific Research, 12(2), 168-175.

Securities Commission Malaysia. (2012). Guidelines on Sukuk. Kuala Lumpur: Securities Commission Malaysia.

Smaoui, H., \& Nechi, S. (2017). Does sukuk market development spur economic growth? Research in International Business and Finance, 41, 136-147.

Tariq, A. A. (2004). Managing financial risks of sukuk structures. Loughborough University, UK.

Usmani, M. T. (2008). Sukuk and their contemporary applications. South Africa: Mujlisul Ulama of South Africa, 1-15. Retrieved from http://www.sukuk.com/library/education/MuftiTaqiSukukpaper.pdf

Wee, B. Van, \& Banister, D. (2016). How to write a literature review paper? Transport Reviews, 36(2), 278-288.

Wilson, R. (2008). Innovation in the structuring of Islamic sukuk securities. Humanomics, 24(3), 170-181. https:// doi.org/10.1108/08288660810899340 